\title{
The Dark Side of the Chinese Stock Market: Managerial Rent-Seeking through Equity Incentives
}

\author{
Li-jun Zhao ${ }^{1} \&$ Zheng-wei Wang ${ }^{2}$ \\ ${ }^{1}$ School of Economics and Management, Tsinghua University, Beijing, China \\ ${ }^{2}$ PBC School of Finance, Tsinghua University, Beijing, China \\ Correspondence: Li-jun Zhao, School of Economics and Management, Tsinghua University, 100084, Beijing, \\ China. E-mail: 785156256@qq.com
}

Received: January 20, 2016

Accepted: February 16, 2016

Online Published: March 25, 2016

doi:10.5539/ijef.v8n4p156

URL: http://dx.doi.org/10.5539/ijef.v8n4p156

\begin{abstract}
Despite widespread attention, most previous papers have failed to test the real effects of equity-based compensation because of endogeneity. In this study, we collected data from the Chinese companies listed in the Shanghai and Shenzhen stock markets from 2006 to 2012. After controlling the problem of endogeneity and selection bias, the results show that equity incentives have no significant influence on improving firm performance. Moreover, these companies were more likely to propose an equity incentive plan when the executives expected that it would be easy to satisfy the vesting conditions. Based on these facts, equity incentives have become managerial rent-seeking for the executives in the Chinese stock market. This is certainly not fair for the investors in the stock market. This paper uses one new method to study the real effects of equity incentives and contributes to the research on the Chinese stock markets and their compensation structures.
\end{abstract}

Keywords: analysts' predictions, equity incentives, firm performance, managerial rent-seeking, two-stage "treatment effect" model

\section{Introduction}

Equity incentives were first adopted by American firms. Based on the academic research on agency problems, many listed companies in the United States began to come up with equity incentive plans. From 1980 to 1994, the percentage of the salaries of chief executive officers(CEOs) that came from stock rewards increased by three times and six years later this number increased by another two times (Hall \& Liebman, 1998). According to Forbes (1998), 40\% of the senior management's income was paid by stock options.

Equity incentives are relatively new in China, because the Chinese stock market is only 25 years old. Most of the first listed companies were state-owned and their executives usually were government officers at the same time. It was not proper to give them high salaries through equity incentive plans due to the concern of corruption. As more and more private companies get listed, various compensation plans become practical. On December 31, 2005, the Chinese Securities Exchange Commission (SEC) announced Equity Incentive "Measures for the Administration of Listed Companies", which was a signal for Chinese listed companies to use equity incentives as a management tool. By 2013, 611 firms, a number that is almost one quarter of all the listed companies, had announced equity incentive plans. As shown in Figure1, the number of equity incentive plans has increased year by year. Many studies on this topic have provided positive results using data from the US stock market.

However, the US capital market has more than 100 years of history before stock options were adopted. It is a more mature market compared with the Chinese one. In the United States, there are more institutional investors and they can tell good plans from the bad ones. But in China, most investors are individuals and they have no advantages compared to institutional investors when it comes to digging up information. What's more, the SEC monitoring regulations are complete in the United States, but not in China. So the effects of equity incentives in China remain to be tested.

Xiao (2009) pointed out that Chinese listed companies are likely to conduct earnings management before and after they come up with incentive plans. The executives manipulated their company's accounting profits to influence the stock price, so that they could get more personal benefits. Lv (2009) thought that these plans may be one kind of welfare for management, so he separated these companies with incentive plans into two groups: 
the welfare group and the incentive group. By comparing the cumulative abnormal returns (CAR) of the two groups when they came up with their plans, he argued that some incentive plans by the Chinese listed companies were actually welfare bonuses for their executives.

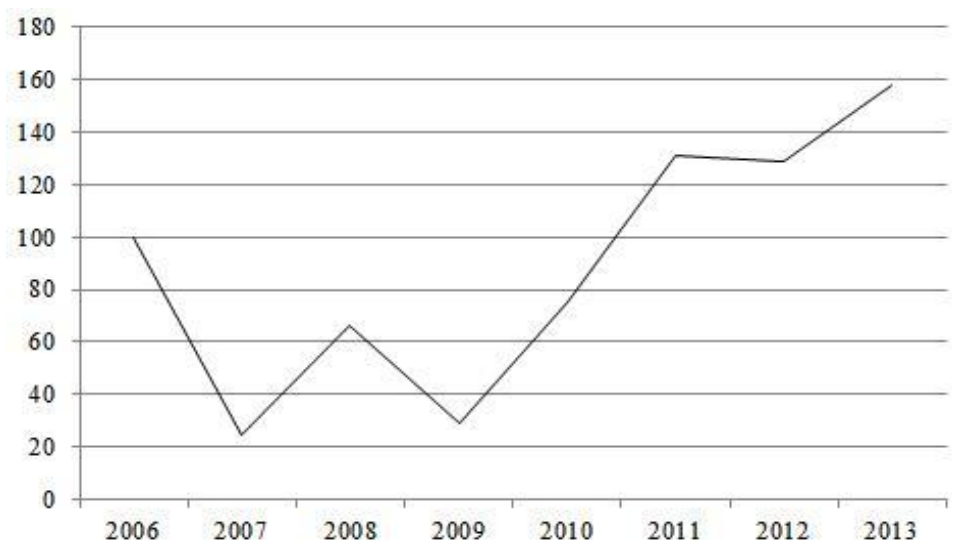

Figure 1. The number of Chinese listed companies with an incentive plan

According to the studies above, if there were no strong market regulations, incentive plans cannot improve the financial performance of a company. On the contrary, it becomes one way to send out bonuses to the executives and do a benefits transfer. In other words, the executives seek managerial rent through equity incentives. Instead of relieving agency problem, this even makes it worse. To avoid this, the Chinese SEC announced three more regulations in May 2008.

The key to deciding whether an equity incentive plan is a bonus for the executives is to look at how the company set the vesting conditions. If the executives are aware or quite sure that the company's growth rate will be high in the next few years and they set a lower vesting condition compared to the real growth rate, then they are using the equity incentive plan to get personal benefits. Only growth beyond expectations can be seen as the result of incentive plans. So the incentive plans are actually the endogenous selective behavior of the listed companies. For academic studies, the most difficult part in studying an incentive plan's effects lies in judging the vesting conditions objectively and fairly.

In this study, we collected data from companies listed in the Chinese stock markets from 2006 to 2012, and we used growth predictions (Note 1) made by analysts to measure the expected growth rate. The results show that after controlling endogeneity, an incentive plan has no significant effect in improving firm performance.

The structure of this paper is as follows. In Section 2, we will review the important literature in this area. Section 3 describes the sample selection procedure and method. The empirical results and their interpretation are presented in Section 4. Section 5 summarizes the key findings.

\section{Literature Review}

Equity-based compensation is the product of agency theory. Many researchers believe that equity-based compensation gives managers the right incentive to maximize firm value. Jensen and Murphy (1990) suggested that managers will think as shareholders only when they become real shareholders. Equity-based compensation plays one important role, especially when the cost of monitoring the executive team is very high. Smith and Watts (1992) found that fast-growing firms use stock options more frequently. Because these companies change quickly, it is difficult to monitor the managers. Yermack (1995) provided further evidence for this. He argued that firms with more accounting noise terms in their financial statements were more likely to use equity incentive plans. Actually, relieving the agency problem is not the only reason for equity-based compensation. This kind of compensation plan can attract motivated managers (Oyer \& Schaefer, 2005) and the firm can utilize the work of these managers without paying them a lot of cash right away (Core \& Guay, 2001). Only those contributing to the growth of the firm can enjoy the extra compensation from the rising of its stock price.

Top managers, like most individuals, are portrayed in the literature as being risk-averse. They will become more risk-averse as they get older, so they may drop out of some good projects to avoid making mistakes before their retirement (Lewellen, Wilbur, Loderer, \& Martin, 1987). Smith and Watts (1982) suggested that managers are 
likely to be short-sighted before their retirement. They will cut R\&D to increase short-term profit. These behaviors will harm the firm in the long term. Tying managers' compensation to firm performance motivates them to make more value-maximizing decisions, and it relieves the problem of risk conflicts between shareholders and managers (Harris, Milton, \& Raviv, 1979).

Income tax is also an important factor when firms decide to use stock options as compensation. The managers pay the income tax when they execute the option, not when they get the option, so equity-based compensation reduces their tax burden (Holland \& Lewellen, 1962).

Much empirical evidence has proven that equity-based compensation can improve firm performance. Kaplan (1989) suggested that firm performance improves after management buy-out (MBO). Mehran (1995) found that firm performance is positively related to the percentage of executive compensation that is equity-based. Tzioumis (2007) argued that equity incentive plans can promote return on equity (ROE) and return on assets (ROA). On the other hand, stock market investors usually have positive opinions about these plans, so a company's announcement that they will be using these plans is always accompanied with the rising of their stock price (Westphal, 1999).

But the incentives provided by stock options have also been criticized. Stock options have become increasingly controversial. The recent accounting scandals at Enron, WorldCom, Global Crossing, and other companies have been linked to excessive risk taking and an excessive fixation on stock prices, both allegedly caused by the escalation in option grants (Cassidy, 2002; Madrick, 2003). After more than tripling (after inflation) during the 1990s stock option explosion, the median total pay for CEOs in the S\&P 500 remained relatively stagnant in the early 2000s, and indeed even declined during the 2008-2009 Great Recession (Murphy, 2013). The tax and accounting rules for stock options are always in progress, even in a mature market like the US stock market. For the emerging market in China, the market mechanism and monitoring regulations still need to be completed. In this situation, equity incentive plans are more likely to become a way to seek managerial rent.

Most previous studies on the Chinese stock market treated the choice of stock options as an exogenous variable. But Jensen and Meckling (1976) argued that ownership structure, executive compensation structure, and board composition are determined by each other and by the nature of a firm's business (e.g., business risk, the nature of real assets, cash flow pattern, and firm size).This means the choice is actually endogenous.

This paper takes the relationship between firms' characteristics and compensation structures into consideration, and treats the choice of an incentive plan as an endogenous variable to test its real effects on firm performance. What's more, we invent the variable, predicted growth, to measure the expected real growth. In this way, we can test our hypothesis about whether a firm proposes an equity incentive plan when its executives expect a high growth rate. This paper contributes to the research on the Chinese stock markets and their compensation structures.

\section{The Model and Data Processing}

\subsection{The Model}

Most of the previous research used ordinary least square (OLS) to test the effects of equity incentive plans on firm performance. This model can be described as follows:

$$
Y=\alpha+\beta S T K \_O P T+\gamma \text { Control }+\varepsilon
$$

$Y$ is the dependent variable, namely, the financial performance of the listed companies, usually represented by ROE or ROA. STK_OPT is a dummy variable that stands for whether a company has an incentive plan or not. Control represents all the control variables.

But whether a company uses equity incentives is actually one choice they make according to the situations their company is facing. This means that proposing or not proposing an incentive plan is actually self-selection behavior on the part of the executives. So if we use model (1), there will be selection bias. In order to resolve this problem, we can use the two-stage "treatment effects" model (Greene, 2003).

First, we use the probit model to inspect what kind of company is more likely to use equity incentive plans.

$$
P\left(S T K \_O P T=1\right)=G(a+b Z+e)
$$

$Z$ represents all the variables that affect the probability of using an incentive plan. $e$ is the random disturbance term. We can get the inverse Mills ratio in model (2) to stand for the selection bias of different firms' characteristics.

Second, we put the inverse Mills ratio into model (1) as one additional control variable, and we get the new model: 


$$
Y=\alpha+\beta S T K \_O P T+\gamma \text { Control }+\lambda \text { Mills }+\varepsilon
$$

Lennox, Francis, and Wang (2012) pointed out that many studies neglected the identification problem of model (2) and (3) when they used this method. Actually, if we do not have enough economic reasons, all the control variables except for the inverse mills ratio in model (3) should be included in model (2). At the same time, there must be one exogenous variable that has no effect on $Y$ in model (2) to guarantee the identification of the whole system.

In this study, we chose analysts' predictions as the exogenous variable in model (2). These predictions will have no effect on the real performance of the firms, but they do reflect the phase that the listed companies are now in. If the companies come up with incentive plans to give bonuses or additional welfare to the executives, they usually tend to do this when the predicted growth rate is high. In this situation, it is easy to satisfy the vesting conditions. From an economic aspect, the prediction of the growth rate can do nothing to the real growth rate, but if the executives do propose an incentive plan according to the expected growth rate, we will see that the probability a firm uses an incentive plan is positively related to the growth rate predicted by the analysts. So the variable we chose meets our requirement for an exogenous variable.

\subsection{Data and Variables}

Most of the data used in this study came from the databases RESSET and CSMAR (Note 2). To guarantee the quality of the data, we also checked the related announcements of the listed companies. After comparing the announcement dates and vesting conditions with those we got from the database, we are confident that the data are reliable.

Figure 1 shows that the Chinese listed companies began to use equity incentives in 2006. So we collected our data from 2006 to 2012. Because the accounting data of Chinese listed financial companies are quite different from other Chinese listed firms, we decided to exclude all financial companies from our study. Considering that institutional investors (security companies) have a short history in China and many companies were not covered by their analysts, but analysts' predictions are necessary for the model, we dropped all the companies that were not covered by the security companies. Finally, we got 7623 samples from the 7 years, and 450 companies, which is around $20 \%$ of all the listed companies that have announced equity incentive plans.

We took ROA and ROE to measure the performance of one firm, which is a popular approach in many classical papers. All the key variables are shown in Table 1.

Table 1. Variables and their meanings

\begin{tabular}{|c|c|}
\hline Variables & Meaning \\
\hline ROA & Return on assets, performance of the firm \\
\hline ROE & Return on equity, performance of the firm \\
\hline$S T K \_O P T$ & Dummy variable, 1 means the company has an incentive plan, 0 otherwise \\
\hline GROWTH_PRE & The mean of all predicted revenue growth rates made by the analysts. This stands for the expectations of outsiders. \\
\hline DEBTRATIO & Debt ratio, the liability of the firm can reflect its frequency \\
\hline$M B$ & Market value/book value, reflection of future expectations \\
\hline IND & The percentage of outside directors on the board \\
\hline CEO & Dummy variable, 1 means that the general manager is also the chairman of the board, 0 otherwise \\
\hline SHARE & The share held by the first large shareholder \\
\hline $\ln (S A L E S)$ & Natural logarithm of the revenue \\
\hline$L A G \_A S S E T$ & Natural logarithm of the lagged whole assets by one year \\
\hline PRIVATE & Dummy variable, 1 private firm, 0 state-owned firm \\
\hline$A G E$ & Average age of the board and the executives \\
\hline
\end{tabular}

\section{Empirical Results}

\subsection{Descriptive Analysis}

First, we divided all the companies into two parts by the dummy variable STK_OPT to get some descriptive analysis. The results are shown in Table 2. For convenience, we called the companies with an incentive plan the test group, namely $S T K \_O P T=1$, and the companies without an incentive plan the control group, namely, STK_OPT=0.

From Table 2, we can tell that the ROA and ROE of the test group are $6.8 \%$ and $11.5 \%$, respectively. This is 
obviously a higher level than the control group, whose ROA and ROE are $5.1 \%$ and $9.3 \%$, respectively. We noticed that the average predicted growth rate of the test group is $35 \%$ and for the control group, it is $29 \%$. This may imply our hypothesis that companies tend to come up with an incentive plan when there is a high growth expectation. There is no obvious difference in asset size between the two groups. The debt ratio of the test group is $38 \%$, which is $8 \%$ lower than the control group. The debt ratio is one variable that measures the cash flow of one firm. So this may tell us that cash flow is also a key consideration when firms provide one incentive plan. The stock share that the largest shareholder holds in the test group is $36 \%$, and the whole test group holds $38 \%$. The probability for the CEO and chairman to be one person is higher in the test group. This may imply that the impact of the executives on the board is also one key variable for having an incentive plan or not. And private firms are more likely to have an incentive plan. What's more, the average age of the executives is lower in the test group. This is not quite consistent with the classical papers.

Table 2. Descriptive analysis

\begin{tabular}{lcccccccc}
\hline & \multicolumn{4}{c}{ STK_OPT=1 } & \multicolumn{3}{c}{ STK_OPT $=0$} \\
\cline { 2 - 8 } & Mean & SD & Min & Max & Mean & SD & Min & Max \\
\hline ROA & 0.0681 & 0.0425 & -0.0879 & 0.2994 & 0.0508 & 0.0494 & -0.3123 & 0.3443 \\
ROE & 0.1149 & 0.0750 & -0.2200 & 0.6544 & 0.0930 & 0.0948 & -0.5758 & 0.7222 \\
In(SALES) & 21.2543 & 1.3824 & 18.6119 & 26.9029 & 21.4531 & 1.4553 & 13.9222 & 28.6557 \\
LAG_ASSET & 21.5044 & 1.1964 & 18.9169 & 26.7086 & 21.8374 & 1.2639 & 18.5979 & 28.2821 \\
SHARE & 0.3654 & 0.1512 & 0.0563 & 0.8060 & 0.3881 & 0.1562 & 0.0210 & 0.8941 \\
CEO & 0.2933 & 0.4558 & 0.0000 & 1.0000 & 0.1827 & 0.3865 & 0.0000 & 1.0000 \\
IND & 0.3739 & 0.0629 & 0.1333 & 0.6667 & 0.3640 & 0.0521 & 0.0909 & 0.8000 \\
MB & 3.4400 & 2.4954 & 0.5114 & 21.4529 & 3.4841 & 2.9027 & 0.3236 & 55.8353 \\
DEBTRATIO & 0.3818 & 0.2016 & 0.0075 & 0.8937 & 0.4643 & 0.2048 & 0.0108 & 0.9570 \\
GROWTH_PRE & 0.3545 & 0.3320 & -0.5929 & 3.4260 & 0.2947 & 0.4387 & -0.8922 & 4.6143 \\
PRIVATE & 0.7467 & 0.4354 & 0 & 1 & 0.4297 & 0.4951 & 0 & 1 \\
AGE & 45.71 & 3.3295 & 36 & 57 & 47.40 & 3.2565 & 29 & 59 \\
\hline
\end{tabular}

\subsection{The Regression}

\subsubsection{The OLS Model}

The results of the OLS model tell us the impact of the incentive plan on the firm's performance without considering endogeneity. In this study, we used ROE and ROA to measure the performance of a firm, and we referred to some of the classical literature in this area to choose variables as our control variables. The results are shown in Table 3.

When we use ROE as our dependent variable, $\mathrm{R}^{2}$ is $18.33 \%$. And when we use ROA as our dependent variable, $\mathrm{R}^{2}$ is $36.12 \%$. This means that the explanatory power of our model is relatively good.

According to the regression, we find that revenue is positively related to financial performance and negatively related to asset size. A higher debt ratio will harm the financial performance of a firm. And a company with a higher market to book ratio usually has a better financial performance, because a higher $M B$ ratio implies that the firm is in a new industry and the investors are positive about its future. The coefficient of $I N D$ is significantly negative. This means that the independence of a firm's board cannot promote its financial performance. If the $\mathrm{CEO}$ and the chairman of the board is the same person, the financial performance is worse than when they are not. Higher average age also implies worse performance. For the variable, share, when ROE is used as the dependent variable, it is significant at the $5 \%$ level. But when ROA is used, it is not significant. 
Table 3. The result of OLS model

\begin{tabular}{|c|c|c|}
\hline & \multicolumn{2}{|c|}{ Dependent Variable } \\
\hline & $R O E$ & $R O A$ \\
\hline \multirow[t]{2}{*}{ STK_OPT } & $0.0140 * * *$ & $0.0067 * * *$ \\
\hline & $(3.34)$ & $(3.43)$ \\
\hline \multirow[t]{2}{*}{$\ln (S A L E S)$} & $0.0325^{* * *}$ & $0.0164 * * *$ \\
\hline & $(23.62)$ & $(25.60)$ \\
\hline \multirow[t]{2}{*}{$L A G \_A S S E T$} & $-0.0118 * * *$ & $-0.0052 * * *$ \\
\hline & $(-7.08)$ & $(-6.73)$ \\
\hline \multirow[t]{2}{*}{ DEBT RATIO } & $-0.0926 * * *$ & $-0.1413 * * *$ \\
\hline & $(-16.08)$ & $(-52.80)$ \\
\hline \multirow[t]{2}{*}{$M B$} & $0.0103 * * *$ & $0.0056^{* * *}$ \\
\hline & $(28.60)$ & (33.67) \\
\hline \multirow[t]{2}{*}{$I N D$} & $-0.0887 * * *$ & $-0.0518 * * *$ \\
\hline & $(-4.78)$ & $(-6.02)$ \\
\hline \multirow[t]{2}{*}{$C E O$} & $-0.0050^{*}$ & $-0.0027 * *$ \\
\hline & $(-1.93)$ & $(-2.18)$ \\
\hline \multirow[t]{2}{*}{ SHARE } & $0.0150 * *$ & 0.0049 \\
\hline & $(2.30)$ & $(1.63)$ \\
\hline \multirow[t]{2}{*}{ PRIVATE } & $0.0061 * * *$ & $0.0022 * *$ \\
\hline & $(2.65)$ & (2.09) \\
\hline \multirow[t]{2}{*}{$A G E$} & $-0.0018 * * *$ & $-0.0006^{* * *}$ \\
\hline & $(-5.28)$ & $(-3.54)$ \\
\hline Obs & 7623 & 7623 \\
\hline $\operatorname{Adj}-R^{2}$ & 0.1833 & 0.3612 \\
\hline
\end{tabular}

Note. $* * *$ significant at $1 \%$ level; ** significant at $5 \%$ level; * significant at $10 \%$ level; the numbers in () are the t statistics.

Actually, the variable we are most concerned within Table 3 is STK_OPT.STK_OPT is significantly positive at the $1 \%$ level no matter whether ROE or ROA is used as the dependent variable. If one firm has an incentive plan, the ROA will be promoted by $0.67 \%$ and its ROE will be promoted by $1.4 \%$. Along with the descriptive analysis in Table 2, this is actually a very big promotion. This result is the most important reason for firms to defend their incentive plans. Also, based on this, many researchers think an equity incentive plan is a good management tool. But just as this paper said before, this model has a big problem with endogeneity. Whether a firm comes up with an incentive plan or not is a decision they make based on the situation of their firm. So STK_OPT cannot be treated as an exogenous variable. The results of the OLS model are not consistent and validated. So we need the two-stage "treatment effects" model to solve this problem.

\subsubsection{Two-Stage "Treatment Effects" Model}

As we said in Section 3, we used this model to solve the problem of endogeneity. We have mentioned the requirement for the exogenous variable. And in this study, we took the revenue growth rate predicted by the analysts (GROWTH_PRE) as our variable. The announcement of an incentive plan can affect the analysts' predictions, so we only chose the predictions made before the announcement date. The results of model (2) and model (3) are shown in Table 4.

Model (2) is a probit model, and its $\mathrm{R}^{2}$ is $8.65 \%$. Since the dependent variable is a dummy variable, the explanatory power of this model is also acceptable. In this model, the most important thing we are concerned about is whether the listed firms create incentive plans according to the expected growth. And we can see that the variable GROWTH_PRE is significant at the 5\% level. Since the predictions made by the analysts are exogenous and they stand for the expectations of the investors for the company, this result proves our hypothesis. The executives know the inner information of the company, so they tend to come up with an incentive plan when they expect a higher growth rate. 
Table 4. The result of two-stage "treatment effects" model

\begin{tabular}{|c|c|c|c|}
\hline & \multirow{3}{*}{$\begin{array}{c}\text { The First Stage } \\
\text { Dependent Variable } \\
\operatorname{Pr}\left(S T K_{-} O P T=1\right)\end{array}$} & \multicolumn{2}{|c|}{ The Second Stage } \\
\hline & & Dependent Variable & Dependent Variable \\
\hline & & $R O E$ & $R O A$ \\
\hline \multirow{2}{*}{$S T K \_O P T$} & I & -0.0317 & 0.0177 \\
\hline & l & $(-1.00)$ & $(1.21)$ \\
\hline \multirow{2}{*}{ GROWTH_PRE } & $0.1101^{* *}$ & I & l \\
\hline & (1.99) & l & l \\
\hline \multirow{2}{*}{$\ln (S A L E S)$} & $0.2328 * * *$ & $0.0335^{* * *} *$ & $0.0161 * * *$ \\
\hline & $(6.17)$ & $(21.80)$ & $(22.58)$ \\
\hline \multirow{2}{*}{$L A G \_A S S E T$} & $-0.1207^{* * *}$ & $-0.0123^{* * *}$ & $-0.0051 * * *$ \\
\hline & $(-2.69)$ & $(-7.23)$ & $(-6.46)$ \\
\hline \multirow{2}{*}{ DEBT RATIO } & $-0.9196 * * *$ & $-0.0969 * * *$ & $-0.1402 * * *$ \\
\hline & $(-6.14)$ & $(-14.97)$ & $(-46.60)$ \\
\hline \multirow{2}{*}{$M B$} & -0.0125 & $0.0102 * * *$ & $0.0056^{* * *}$ \\
\hline & $(-1.23)$ & $(28.42)$ & (33.64) \\
\hline \multirow{2}{*}{$I N D$} & $1.3361 * * *$ & $-0.0811^{* * *}$ & $-0.0537 * * *$ \\
\hline & $(3.10)$ & $(-4.22)$ & $(-6.00)$ \\
\hline \multirow{2}{*}{ CEO } & 0.0329 & $-0.0047 *$ & $-0.0027 * *$ \\
\hline & $(0.56)$ & $(-1.78)$ & $(-2.24)$ \\
\hline \multirow{2}{*}{ SHARE } & $-0.4906^{* * * *}$ & $0.0130 * *$ & $0.0054^{*}$ \\
\hline & $(-2.98)$ & $(1.96)$ & $(1.75)$ \\
\hline \multirow{2}{*}{ PRIVATE } & $0.4754 * * *$ & $0.0084 * * *$ & 0.0017 \\
\hline & $(8.07)$ & (3.01) & $(1.29)$ \\
\hline \multirow{2}{*}{$A G E$} & $-0.0538 * * *$ & $-0.0021 * * *$ & $-0.0005^{* * *}$ \\
\hline & $(-6.49)$ & $(-5.28)$ & $(-2.64)$ \\
\hline Obs & 7623 & 7623 & 7623 \\
\hline Pseudo/Adj-R ${ }^{2}$ & 0.0865 & 0.1835 & 0.3611 \\
\hline
\end{tabular}

Note. $* * *$ significant at $1 \%$ level; ** significant at $5 \%$ level; * significant at $10 \%$ level; the numbers in () are the t statistics.

Most of the independent variables in the OLS model are significant in the probit model. Just as Lennox, Francis, and Wang (2012) said in their paper, unless we have enough economic reasons, all the variables in the second stage should be put in the probit model.

The regression of the second stage tells us the real effect of the equity incentive plan after controlling the problem of endogeneity and selection bias. First, we pay attention to the explanatory variable, STK_OPT. In Table 4, we can see that STK_OPT is no longer significant, no matter whether we use ROE or ROA as the explained variable. Compared with the result in Table 3, the two-stage "treatment effects" model gives out an obviously different result (in Table 3, STK_OPT is significantly positive). The regression has proved our hypothesis that a company tends to come up with an incentive plan based on the expectations they have about the growth of the company. In this way, the incentive plan actually does nothing to promote the financial performance of the company, since all the growth has been expected.

Comparing the other variables except for STK_OPT in Tables 3 and 4, their numbers and significance levels are almost the same. This also provides evidence that $S T K \_O P T$ is endogenous and the other control variables are not.

According to the facts above, we believe many Chinese listed companies created incentive plans based on their expected growth rate. These plans actually have no use at all, since all growth has been expected. In other words, the companies can achieve those vesting conditions even without the incentive plans at all. In this way, the incentive plans of these Chinese companies are extra welfare for their executives at the cost of the investors.

\subsection{Robustness Test}

We deleted those samples that were not covered by the analysts. To guarantee the comparability of the results in models (1), (2), and (3), we used the same data. But this method of data processing casts another problem. Is there selection bias when the analysts chose their research subjects? We noticed that the variable, GROWTH_PRE, is not used in model (1). So we used the complete data before deletion to do the regression of 
model (1) again. The results are shown in Table 5.

Table 5. The OLS model based on complete data

\begin{tabular}{|c|c|c|}
\hline & \multicolumn{2}{|c|}{ Dependent Variable } \\
\hline & $R O E$ & $R O A$ \\
\hline \multirow{2}{*}{$S T K \_O P T$} & $0.0184 * * *$ & $0.0100 * * *$ \\
\hline & $(4.00)$ & $(4.73)$ \\
\hline \multirow{2}{*}{$\ln (S A L E S)$} & $0.0364 * * *$ & $0.0180^{* * *}$ \\
\hline & $(30.58)$ & $(32.81)$ \\
\hline \multirow{2}{*}{$L A G \_A S S E T$} & $-0.0169 * * *$ & $-0.0079 * * *$ \\
\hline & $(-11.43)$ & $(-11.61)$ \\
\hline \multirow{2}{*}{ DEBT RATIO } & $-0.0854 * * *$ & $-0.1192 * * *$ \\
\hline & $(-16.05)$ & $(-48.53)$ \\
\hline \multirow{2}{*}{$M B$} & $0.0029 * * *$ & $0.0013^{* * * *}$ \\
\hline & (18.36) & $(18.41)$ \\
\hline \multirow{2}{*}{$I N D$} & $-0.0422 * *$ & $-0.0319 * * *$ \\
\hline & $(-2.29)$ & $(-3.76)$ \\
\hline \multirow{2}{*}{$C E O$} & $-0.0058^{* *}$ & $-0.0028 * *$ \\
\hline & $(-2.24)$ & $(-2.35)$ \\
\hline \multirow{2}{*}{ SHARE } & $0.0448 * * *$ & $0.0208 * * *$ \\
\hline & $(6.94)$ & $(6.97)$ \\
\hline \multirow{2}{*}{ PRIVATE } & $0.0160 * * *$ & $0.0078^{* * *}$ \\
\hline & $(7.27)$ & $(7.72)$ \\
\hline \multirow{2}{*}{$A G E$} & $-0.0020 * * *$ & $-0.0007 * * *$ \\
\hline & $(-5.95)$ & $(-4.89)$ \\
\hline Observations & 11036 & 11036 \\
\hline Adjusted $\mathrm{R}^{2}$ & 0.1378 & 0.2515 \\
\hline
\end{tabular}

Note. $* * *$ significant at $1 \%$ level; $* *$ significant at $5 \%$ level; * significant at $10 \%$ level; the numbers in () are the $\mathrm{t}$ statistics.

Comparing Table 3 with Table 5, we find the significance and the number of all variables do not change at a high level, especially the variable $S T K_{-} O P T$. This means the selection bias of our data processing is not that large. But in the two-stage "treatment effects" model, we need the variable GROWTH_PRE, so we cannot see the impact of data deletion. In our future research, we will try to find other exogenous variables. And as time passes, more firms will have incentive plans and we will have more samples. The impact of the missing data will get weaker.

\section{Conclusion}

Many studies have proven that equity incentive plans can relieve the agency problem and improve firm performance. But most of these studies are based on data from the US stock market. The stock market in China has a history of less than 30 years and the first equity incentive plan was created only 10 years ago, so many regulatory ordinances need to be created. Additionally, most investors in China are individual investors, and usually, they cannot tell a good plan from a bad one. So the market mechanism cannot constrain the companies very well. In this situation, equity incentive plans become one way for the executives to seek managerial rent.

In this paper, we studied this issue with new logic. What is the role that incentive plans play in the growth of companies? Does the plan indeed promote the company's growth, or does the expected growth induce the company to come up with a plan? In this paper, we take analysts' predictions as the proxy variable of expected growth to test the real effects of equity incentive plans. When not considering the problem of endogeneity, the incentive plans do seem to have incentive effects and can improve firm performance. But after controlling endogeneity, those plans are no longer significant in promoting performance. In this way, these plans do not achieve their expected effects and become a kind of benefits transfer at the cost of investors.

\section{References}

Baker, T., Collins, D., \& Reitenga, A. (2003). Stock option compensation and earnings management incentives. Journal of Accounting, Auditing \& Finance, 18(4), 557-582.

Barkema, H. G., \& Gomez-Mejia, L. R. (1998). Managerial Compensation and Firm Performance: A General 
Research Framework. Academy of Management journal, 41(2), 135-145. http://dx.doi.org/10.2307/257098

Changjiang, L., Xiulian, Z., Mingzhu,Y., \& Jingjing, X. (2009). The Design for Listed Companies' System of Stimulation by Stock Option and Purchase: Is it an Incentive or Welfare? Management World, (9), 133-147.

Core, J., \& Guay, W. (1999). The use of equity grants to manage optimal equity incentive levels. Journal of Accounting and Economics, 28(2), 151-184. http://dx.doi.org/10.1016/S0165-4101(99)00019-1

Demsetz, H., \& Lehn, K. (1985). The structure of corporate ownership: Causes and consequences. The Journal of Political Economy, 1155-1177. http://dx.doi.org/10.1086/261354

Greene, W. H. (2003). Econometric analysis. Pearson Education India.

Grossman, S. J., \& Hart, O. D. (1983). An analysis of the principal-agent problem. Econometrica: Journal of the Econometric Society, 7-45. http://dx.doi.org/10.2307/1912246

Hall, B. J., \& Liebman, J. B. (1997). Are CEOs really paid like bureaucrats?(No. w6213). National bureau of economic research. http://dx.doi.org/10.2139/ssrn.2086

Harris, M., \& Raviv, A. (1979). Optimal incentive contracts with imperfect information. Journal of Economic Theory, 20(2), 231-259. http://dx.doi.org/10.1016/0022-0531(79)90073-5

Heckman, J. J. (1979). Sample selection bias as a specification error. Econometrica: Journal of the Econometric Society, 153-161. http://dx.doi.org/10.2307/1912352

Hermalin, B. E., \& Weisbach, M. S. (1991). The effects of board composition and direct incentives on firm performance. Financial Management, 101-112. http://dx.doi.org/10.2307/3665716

Holland, D. M., \& Lewellen, W. G. (1962). Probing the Record of Stock-Options. Harvard Business Review, 40(2), 132-150.

Jackson, S. B., Liu, X. K., \& Cecchini, M. (2009). Economic consequences of firms' depreciation method choice: Evidence from capital investments. Journal of Accounting and Economics, 48(1), 54-68.

Jensen, M. C., \& Meckling, W. H. (1976). Theory of the firm: Managerial behavior, agency costs and ownership $\begin{array}{llll}\text { structure. Journal of } & \text { Financial }\end{array}$ http://dx.doi.org/10.1016/0304-405X(76)90026-X

Jensen, M. C., \& Murphy, K. J. (2010). CEO Incentives-It's Not How Much You Pay, But How. Journal of Applied Corporate Finance, 22(1), 64-76. http://dx.doi.org/10.1111/j.1745-6622.2010.00262.x

Kaplan, S. (1989). The effects of management buyouts on operating performance and value. Journal of Financial Economics, 24(2), 217-254. http://dx.doi.org/10.1016/0304-405X(89)90047-0

Lazear, E. P. (1999). Output-based pay: incentives or sorting? (No. w7419). National Bureau of Economic Research.

Lennox, C. S., Francis, J. R., \& Wang, Z. (2011). Selection models in accounting research. The Accounting Review, 87(2), 589-616. http://dx.doi.org/10.2308/accr-10195

Leuz, C., \& Verrecchia, R. E. (2000). The Economic Consequences of Increased Disclosure (Digest Summary). Journal of Accounting Research, 38, 91-124. http://dx.doi.org/10.2307/2672910

Lewellen, W., Loderer, C., \& Martin, K. (1987). Executive compensation and executive incentive problems: An empirical analysis. Journal of Accounting and Economics, 9(3), 287-310. http://dx.doi.org/10.1016/0165-4101(87)90009-7

Mehran, H. (1995). Executive compensation structure, ownership, and firm performance. Journal of Financial Economics, 38(2), 163-184. http://dx.doi.org/10.1016/0304-405X(94)00809-F

Oyer, P. (2004). Why do firms use incentives that have no incentive effects? The Journal of Finance, 59(4), 1619-1650. http://dx.doi.org/10.1111/j.1540-6261.2004.00674.x

Oyer, P., \& Schaefer, S. (2006). Costs of broad-based stock option plans. Journal of Financial Intermediation, 15(4), 511-534. http://dx.doi.org/10.1016/j.jfi.2005.09.003

Rosenberg, M. (2003). Corporate governance mechanisms and firm performance: Evidence from Finland. Swedish School of Economics and Business Administration.

Sanders, W. G. (2001). Behavioral responses of CEOs to stock ownership and stock option pay. Academy of Management Journal, 44(3), 477-492. http://dx.doi.org/10.2307/3069365 
Shufang, X., Chenyu, Z., Chao, Z., \& Ran, X. (2009). Earnings Management prior to the Public Disclosure of an Equity Incentive Plan: Empirical Evidence from Listed Companies in China. Nankai Business Review, (4), 113-119.

Sloan, R. G. (1993). Accounting earnings and top executive compensation. Journal of Accounting and Economics, 16(1), 55-100. http://dx.doi.org/10.1016/0165-4101(93)90005-Z

Smith, C. W., \& Watts, R. L. (1982). Incentive and tax effects of executive compensation plans. Australian Journal of Management, 7(2), 139-157. http://dx.doi.org/10.1177/031289628200700204

Smith, C. W., \& Watts, R. L. (1992). The investment opportunity set and corporate financing, dividend, and compensation policies. Journal of Financial Economics, 32(3), 263-292. http://dx.doi.org/10.1016/0304-405X(92)90029-W

Tzioumis, K. (2008). Why do firms adopt CEO stock options? Evidence from the United States. Journal of Economic Behavior \& Organization, 68(1), 100-111. http://dx.doi.org/10.1016/j.jebo.2007.06.008

Westphal, J. D. (1999). Collaboration in the boardroom: Behavioral and performance consequences of CEO-board social ties. Academy of Management Journal, 42(1), 7-24. http://dx.doi.org/10.2307/256871

\section{Notes}

Note 1 . There are many security companies (investment banks) in China. One of their most important jobs is to issue research reports about the listed companies. Usually they will make predictions about the operating data of the listed companies in these reports.

Note 2. The two databases are professional financial databases focusing on the data of Chinese listed companies.

\section{Copyrights}

Copyright for this article is retained by the author(s), with first publication rights granted to the journal.

This is an open-access article distributed under the terms and conditions of the Creative Commons Attribution license (http://creativecommons.org/licenses/by/3.0/). 